УдК 796.41:796.012.1

ISSN (Ukrainian ed. Print) 1991-0177 ISSN (Ukrainian ed. Online) 1999-818X 2021, № 1(81), C.89-94 doi:10.15391/snsv.2021-1.012

\begin{abstract}
Михайло Марченков Олена Насонкіна
\end{abstract}

\section{Підвищення рівня розвитку силових здібностей спортсменів віком 10-11 років в акробатичному рок-н-ролі}

Харківська державна академія фізичної культури, Харків, Україна

\begin{abstract}
Мета: обгрунтувати ефективність авторської програми комплексного розвитку силових здібностей спортсменів 10-11 років, які займаються акробатичним рок-н-ролом.

Матеріал і методи: дослідження проводилося у період з вересня 2019 року до жовтня 2020 року на базі клубу акробатичного рок-н-ролу «SUMMIT» м. Харків. В дослідженні прийняло участь 20 юних спортсменів віком 10 - 11 років (10 хлопців та 10 дівчат). Усі досліджувані спортсмени займалися у групі попередньої базової підготовки 1-го року навчання. У роботі були використані наступні методи: аналіз і узагальнення науково-методичної літератури; педагогічний експеримент; методи математичної статистики.

Результати: на основі показників рівня фізичної підготовленості спортсменів, було розроблено тренувальну програму комплексного розвитку силових здібностей юних спортсменів віком 10-11 років, які займаються акробатичним рок-н-ролом. Програма передбачала підвищення рівня розвитку силових здібностей м'язів верхніх кінцівок, шиї, тулуба та ніг. Впровадження програми підготовки сприяло підвищенню рівня розвитку силових здібностей м'язів верхніх кінцівок на 17,5\% у хлопців та на 22\% у дівчат; м'язів тулуба на 12,6\% у хлопців та на 10,2\% у дівчат; сили м'язів ніг на 0,9\% у хлопців та на 0,6\% у дівчат.

Висновки: у результаті проведеного педагогічного експерименту із застосуванням спеціально розробленої тренувальної програми у хлопців достовірно покращився рівень розвитку силових здібностей м'язів верхніх кінцівок, тулуба та ніг ( $p<0,05-0,001)$. У дівчат у результаті впровадження розробленої тренувальної програми достовірно покращився рівень розвитку силових здібностей м'язів верхніх кінцівок ( $p<0,05-0,001)$.
\end{abstract}

Ключові слова: акробатичний рок-н-рол; силові здібності; тренувальна програма, силова підготовки; етап попередньої базової підготовки.

\section{Вступ}

Акробатичний рок-н-рол є відносно новим видом спорту не тільки в Україні, але й в усьому світі. Бурхливий розвиток та зростання його популярності зумовлюють необхідність розробки та науково - методичного обґрунтування специфічних методик різних розділів підготовки спортсменів, особливо початківців, оскільки початкові навички мають визначальний вплив на подальші успіхи.

V. Adashevskiy [6] вважає що спортивна підготовка в акробатичному рок-н-ролі ускладнена технікою виконання, необхідністю засвоєння великої кількості складних за структурою рухових дій, що виконуються в парах з музичним супроводом. B. Blasing, B. Calvo-Merino [8] виявили, що танцювальні елементи та фігури характеризуються особливим стилем виконання - це вимагає значної координованості та вміння узгоджувати рухи практично з усіма ланками тіла.

За даними П. М. Кизіма [3], найважливішими компонентами тренувального процесу $є$ фізична і технічна підготовленість спортсменів, що потребує раціональної методики тренування.
Достатня фізична підготовленість спортсменів забезпечує цілісність, систематичність і безпеку тренувального процесу, а також є критерієм сумісності партнерів для занять спортивними танцями [2, 9].

Оскільки розвиток всіх компонентів силової підготовки дуже важливий в системі підготовки юних спортсменів, які займаються акробатичним рок-н-ролом, та відіграє важливу роль у забезпеченні ефективним володінням технікою акробатичного рок-н-рола проблема оптимізації побудови фізичної підготовки, та особисто силової, є актуальною.

Зв'язок роботи з науковими програмами, планами, темами. Дослідження виконувалося відповідно до теми науково-дослідної роботи кафедри гімнастики, танцювальних видів спорту та хореографії: «Теоретико-методологічні засади розвитку системоутворюючих компонентів фізичної культури (спорт, фізична рекреація, фітнес) (2020-2025 рр.)». Державний реєстраційний номер $0120 \cup 101215$.

Мета дослідження - обґрунтувати ефективність авторської програми комплексного розвитку силових 
\begin{tabular}{rr} 
Таблиця 1 \\
\hline Оцінка рівня фізичної підготовленості
\end{tabular} на початку експерименту (n=20) (за А. I. Сеницею, 2010 [5])

\begin{tabular}{|c|c|c|c|c|c|}
\hline \multirow[t]{3}{*}{ Контрольні тести } & \multicolumn{3}{|c|}{$\begin{array}{c}\text { Нормативні показники } \\
\text { рівня підготовленості } \\
\text { за навчальною } \\
\text { програмою для } \\
\text { ДЮСШ (бали) } \\
\end{array}$} & \multicolumn{2}{|c|}{$\begin{array}{c}\text { Середньогрупові } \\
\text { показники силової } \\
\text { підготовленості } \\
\text { досліджуваних } \\
\text { спортсменів }\end{array}$} \\
\hline & $\ll \mathbf{5} »$ & $\ll 4 »$ & $\ll \mathbf{3} »$ & К-ть разів & бали \\
\hline & \multicolumn{5}{|c|}{ Хлопиі $(n=10)$} \\
\hline $\begin{array}{c}\text { Підтягування на перекладині, } \\
\text { к-ть разів }\end{array}$ & 6 & 5 & 4 & 5 & 4 \\
\hline $\begin{array}{c}\text { Згинання і розгинання рук в } \\
\text { упорі лежачи, к-ть разів }\end{array}$ & 12 & 10 & 8 & 9 & 4 \\
\hline $\begin{array}{c}\text { Піднімання прямих ніг до кута } 90^{\circ} \\
\text { у висі спиною до гімнастичної } \\
\text { стінки, к-ть разів }\end{array}$ & 10 & 8 & 6 & 8 & 4 \\
\hline Біг 30 м з високого старту, с & 5,5 & 5,8 & 6,0 & 5,7 & 4 \\
\hline Стрибки у довжину з місця, см & 175 & 170 & 165 & 169 & 4 \\
\hline \multicolumn{6}{|c|}{ Дівчата $(n=10)$} \\
\hline $\begin{array}{c}\text { Підтягування на перекладині, } \\
\text { к-ть разів }\end{array}$ & 4 & 3 & 2 & 3 & 4 \\
\hline $\begin{array}{c}\text { Згинання і розгинання рук в } \\
\text { упорі лежачи, к-ть разів }\end{array}$ & 10 & 8 & 6 & 8 & 4 \\
\hline $\begin{array}{l}\text { Піднімання прямих ніг до кута } \\
90^{\circ} \text { у висі спиною до } \\
\text { гімнастичної стінки, к-ть разів }\end{array}$ & 8 & 6 & 4 & 6 & 4 \\
\hline Біг 30 м з високого старту, с & 6,5 & 6,7 & 7,0 & 6,7 & 4 \\
\hline Стрибки у довжину з місця, см & 160 & 155 & 150 & 156 & 4 \\
\hline
\end{tabular}

здібностей спортсменів 10-11 років, які займаються акробатичним рок-н-ролом.

\section{Матеріал і методи дослідження}

Дослідження проводилося у період з вересня 2019 року до жовтня 2020 року на базі клубу акробатичного рок-н-ролу «SUMMIT» M. Харків. В дослідженні прийняло участь 20 юних спортсменів віком 10-11 років (10хлопців та 10 дівчат), що займалися в групі попередньої базової підготовки 1-го року навчання. У роботі були використані наступні методи: аналіз і узагальнення науково-методичної літератури; педагогічний експеримент; методи математичної статистики.

\section{Результати дослідження}

На початку дослідження, з метою розробки тренувальної програми, було визначено відповідність рівня фізичної підготовленості досліджуваних спортсменів їх віковим особливостям таблиця 1.

На підставі отриманих даних виявлено, що ступінь розвитку сили м'язів верхніх кінцівок і тулубу та сили ніг відповідає середньому рівню (оцінка 4 бали).

На підставі отриманих даних було розроблено тренувальну програму комплексного розвитку силових здібностей юних спортсменів віком 10-11 років, які займаються акробатичним рок-н-ролом, і перебувають на етапі попередньої базової підготовки. Розроблена програма була впроваджена у навчально-тренувальний процес і включала фізичні вправи, які було спрямовано на комплексний розвиток швидкісно-силових та відносно-силових здібностей. Під час констатувального та формувального експерименту група юних спортсменів щодня виконувала спеціально складені комплекси фізичних вправ, спрямованих на розвиток сили м'язів верхніх кінцівок, м'язів шиї і тулуба та м'язів ніг.

В основній частині навчально-тренувального заняття після розв'язання завдань технічної підготовки виконувалися фізичні вправи, спеціально спрямовані на комплексний розвиток силових здібностей. Перші три дні тижня (понеділок, вівторок і середа) застосовувалися вправи, спрямовані на розвиток швидкісно-силових здібностей. Наприкінці тижня (четвер, п'ятниця і субота) застосовувалися вправи, спрямовані на розвиток відносно-силових здібностей.

Після впровадження експериментальної програми силової підготовки досліджуваного контингенту спортсменів було визначено достовірні зміни в показниках прояву силових здібностей (табл. 2, 3). 


\section{Показники рівня розвитку силових здібностей досліджуваних хлопців за період дослідження $(\mathrm{n}=10)$}

\begin{tabular}{|c|c|c|c|c|}
\hline \multirow{3}{*}{$\begin{array}{c}\text { Контрольні } \\
\text { тести }\end{array}$} & \multicolumn{2}{|c|}{ Показники } & \multirow{3}{*}{$\mathrm{t}$} & \multirow{3}{*}{$\mathrm{P}$} \\
\hline & $\begin{array}{c}\text { на початку } \\
\text { експерименту } \\
n=10\end{array}$ & $\begin{array}{c}\text { наприкінці } \\
\text { експерименту } \\
\text { n=10 }\end{array}$ & & \\
\hline & $\mathrm{X}_{1} \pm \tilde{\mathrm{o}}$ & $\mathrm{X}_{2} \pm \tilde{\mathrm{o}}$ & & \\
\hline $\begin{array}{l}\text { Підтягування на перекладині, } \\
\text { кількість (раз). }\end{array}$ & $5,2 \pm 0,8$ & $6,3 \pm 1,2$ & 4,71 & $<0,01$ \\
\hline $\begin{array}{c}\text { Згинання і розгинання рук в упорі } \\
\text { лежачи, кількість (раз). }\end{array}$ & $9,4 \pm 1,4$ & $10,7 \pm 1,7$ & 4,99 & $<0,001$ \\
\hline $\begin{array}{c}\text { Піднімання прямих ніг до кута 90 } \\
\text { у висі спиною до гімнастичної } \\
\text { стінки, кількість (раз). }\end{array}$ & $8,3 \pm 1,3$ & $9,5 \pm 1,7$ & 4,81 & $<0,001$ \\
\hline $\begin{array}{c}\text { Біг } 30 \text { м } 3 \text { високого } \\
\text { старту (c). }\end{array}$ & $5,71 \pm 0,2$ & $5,66 \pm 0,2$ & 1,46 & $>0,05$ \\
\hline $\begin{array}{c}\text { Стрибки у довжину } \\
\text { з місця (см) }\end{array}$ & $169,1 \pm 2,8$ & $170,6 \pm 3,9$ & 2,24 & $<0,05$ \\
\hline
\end{tabular}

Примітка: tкр. 2,23

Таблиця 3

Показники рівня розвитку силових здібностей досліджуваних дівчат за період дослідження $(\mathbf{n}=10)$

\begin{tabular}{|c|c|c|c|c|}
\hline \multirow{3}{*}{$\begin{array}{c}\text { Контрольні } \\
\text { тести }\end{array}$} & \multicolumn{2}{|c|}{ Показники } & \multirow{3}{*}{$\mathrm{t}$} & \multirow{3}{*}{$\mathrm{P}$} \\
\hline & $\begin{array}{c}\text { на початку } \\
\text { експерименту } \\
n=10\end{array}$ & $\begin{array}{c}\text { наприкінці } \\
\text { експерименту } \\
\text { n=10 }\end{array}$ & & \\
\hline & $\mathrm{X}_{1} \pm \tilde{\mathrm{o}}$ & $\mathrm{X}_{2} \pm \tilde{\mathrm{o}}$ & & \\
\hline $\begin{array}{c}\text { Підтягування на перекладині, } \\
\text { кількість (раз) }\end{array}$ & $3,2 \pm 0,8$ & $4,1 \pm 1,0$ & 3,86 & $<0,01$ \\
\hline $\begin{array}{c}\text { Згинання і розгинання рук в упорі } \\
\text { лежачи, кількість (раз). }\end{array}$ & $7,8 \pm 1,6$ & $8,9 \pm 1,9$ & 4,71 & $<0,01$ \\
\hline $\begin{array}{c}\text { Піднімання прямих ніг до кута 90 } \\
\text { у висі спиною до гімнастичної } \\
\text { стінки, кількість (раз). }\end{array}$ & $6,2 \pm 1,5$ & $6,9 \pm 1,7$ & 2,08 & $>0,05$ \\
\hline $\begin{array}{c}\text { Біг } 30 \text { м з високого } \\
\text { старту (с). }\end{array}$ & $6,71 \pm 0,2$ & $6,68 \pm 0,2$ & 1,15 & $>0,05$ \\
\hline $\begin{array}{c}\text { Стрибки у довжину } \\
\text { з місця (см). }\end{array}$ & $156,2 \pm 3,1$ & $157,1 \pm 3,1$ & 2,08 & $>0,05$ \\
\hline
\end{tabular}

Примітка: tкр. 2,23

Аналіз отриманих даних виявив достовірні зміни після впровадження експериментальної програми $(\mathrm{p}<0,05$ $0,001)$ у показниках прояву сили м'язів верхніх кінцівок, які визначалися за допомогою тесту згинанням і розгинанням рук в упорі лежачи і підтягуванням на перекладині, як у хлопців так і у дівчат.

У хлопців застосована експериментальна програма мала позитивну дію на підвищення рівня силових здіб- ностей м'язів тулуба, про що свідчать достовірні покращення результатів виконання тесту підніманням прямих ніг до кута $90^{\circ}$ у висі спиною до гімнастичної стінки $(\mathrm{p}<0,001)$.

При виконанні інших тестових вправ встановлено, що результати як у хлопців так і у дівчат мали тенденцію до підвищення, але ці розрізнення виявилися не суттєвими $(p>0,05)$. 


\section{СЛОБОЖАНСЬКИЙ НАУКОВО-СПОРТИВНИЙ ВІСНИК}

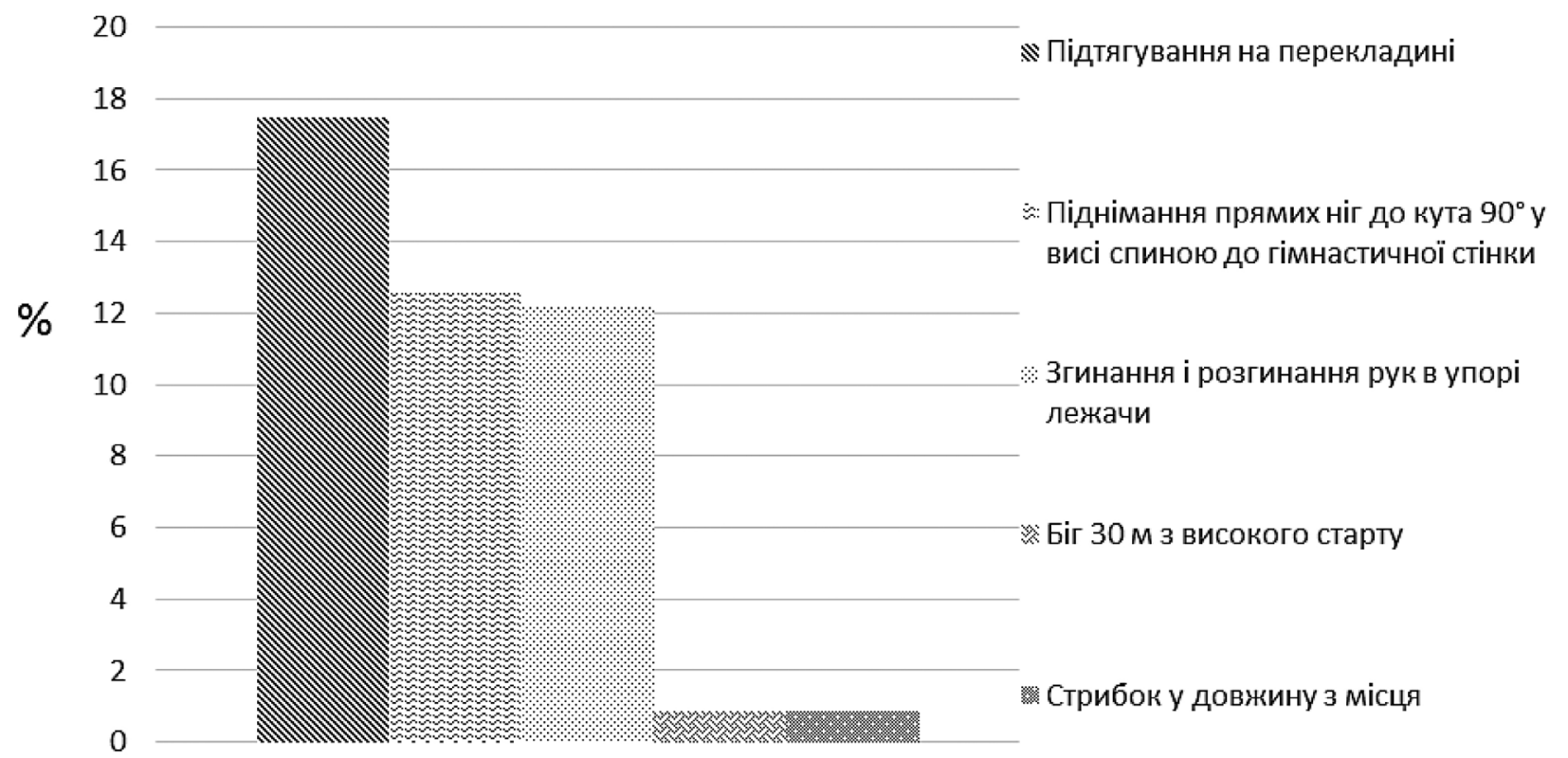

Рис. 1. Приріст показників рівня розвитку швидкісно-силових та відносно-силових здібностей досліджуваних хлопців за період експерименту

25

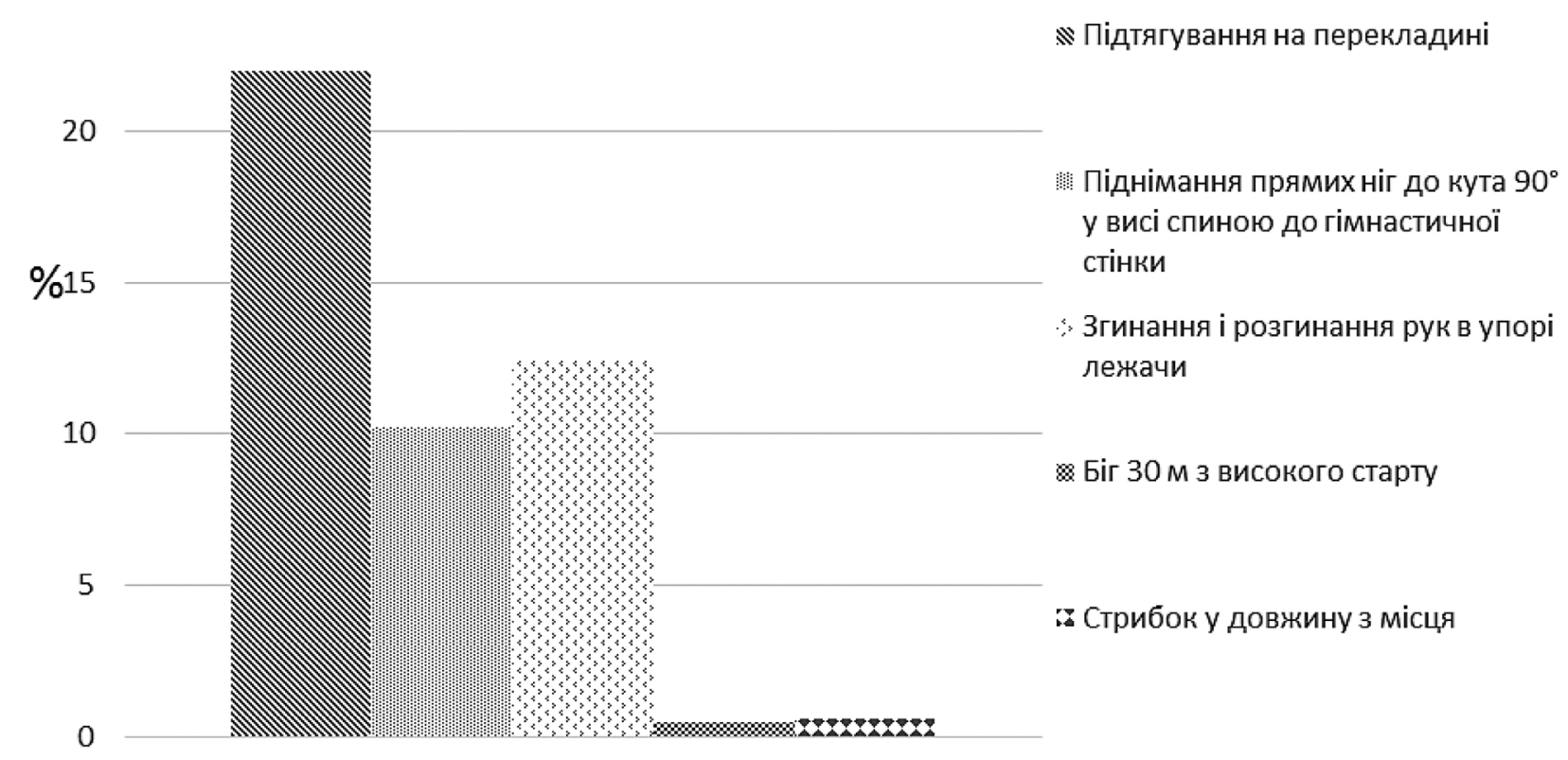

Рис. 2. Приріст показників рівня розвитку швидкісно-силових та відносно-силових здібностей досліджуваних дівчат за період експерименту

3 метою визначення впливу розробленої програми підготовки, було розраховано прирости показників рівня розвитку швидкісно-силових та відносно-силових здібностей досліджуваних спортсменів (рис. 1, 2).

Аналіз приросту результатів хлопців виявив найбільший вплив розробленої програми силової підготовки на рівень розвитку силових здібностей м'язів верхніх кінцівок 17,5 \% та тулуба 12,6\%. Найменший вплив розроблена програма тренування мала на рівень розвитку швидкісної сили хлопців 0,9\%.
Аналіз результатів приросту показників силової підготовленості дівчат виявив найбільш ефективну дію розробленої програми на рівень розвитку силових здібностей м'язів верхніх кінцівок $22 \%$. Найменший вплив розроблена програми як і у хлопців спостерігався на рівень розвитку швидкісної сили $0,6 \%$.

\section{Висновки / Дискусія}

У ході проведеного дослідження підтверджені відомості Л. С. Луценко, Н. П. Батєєвої $[1,4]$ щодо 


\section{СЛОБОЖАНСЬКИЙ НАУКОВО-СПОРТИВНИЙ ВІСНИК}

значимості силових здібностей у підготовці в акробатичному рок-н-ролі. В роботах I. Anca, N. Kim [7, 10] зазначається особлива увага щодо тренування м'язів-згиначів, оскільки від рівня розвитку сили цих груп м'язів багато в чому залежить успіх в оволодінні технікою виконання вправ, однак запропоновані програми силової підготовки не включають комплексний розвиток сили певних групи м'язів. Результати дослідження доповнюють відомості Н. П. Батєєвої, T. Kravchuk [1, 11] стосовно фізичної підготовки в акробатичному рок-н-ролі.

Проведення формувального експерименту із застосуванням спеціально розробленої тренувальної програми комплексного розвитку силових здібностей виявило, що під впливом систематичних тренувань та застосованої експериментальної програми у хлопців спостерігається достовірне покращення показників сили м'язів верхніх кінцівок, тулуба та ніг ( $<<0,05-0,001)$, окрім показників швидкісної сили ( $>>0,05)$, і як наслідок підвищення її рівня з середнього (4 бали) до високого (5 балів). у дівчат у результаті впровадження розробленої тренувальної програми, достовірно покращилися показники сили м'язів верхніх кінцівок ( $p<0,05-0,001)$, і як наслідок підвищення ії̈ рівня з середнього (4 бали) до високого (5 балів). Однак рівень розвитку показників сили м'язів тулуба та ніг (p>0,05) залишився на вихідній позиції - середній (4 бали).

У хлопців розроблена тренувальна програма мала найбільший вплив на рівень розвитку силових здібностей м'язів верхніх кінцівок та тулуба, що у відсотковому співвідношенні становить 17,5 \% і 12,6\% відповідно. У дівчат, в результаті застосування розробленої програми підготовки, найбільші прирости спостерігалися у рівні розвитку силових здібностей м'язів верхніх кінцівок, що у відсотковому співвідношенні становить $22 \%$.

Перспектива подальших досліджень. Передбачається встановити взаємозв'язок між рівнем розвитку швидкісно-силових та відносно-силових здібностей та показниками рівня технічної підготовленості в акробатичному рок-н-ролі.

Конфлікт інтересів. Автори заявляють, що відсутній конфлікт інтересів, який може сприйматись таким, що може завдати шкоди неупередженості статті.

Джерела фінансування. Ця стаття не отримала фінансової підтримки від державної, громадської або комерційної організації.

\section{Список посилань}

1. Батеева Н.П.(2012), «Факторная структура специальной физической подготовленности квалифицированных спортсменов в акробатическом рок-н-ролле», Слобожанський науково-спортивний вісник, №3, С. 69-74.

2. Калужна О. (2010), «Фізична підготовка у тренувальному процесі спортсменів-танцюристів на етапі попередньої базової підготовки», Теорія і методика фізичного виховання і спорту, № 2, С. 12-16.

3. Кизім П. М. (2005), «Модельні характеристики спеціальної фізичної підготовленості спортсменів вищої кваліфікації 3 акробатичного рок-н-ролу», Слобожанський науково-спортивний вісник, № 8, С. 103-105

4. Луценко Л. С., Макурин Ю. К., Муллагильдина А. Я. (2002), «Средства и методы тренировки на этапе начальной подготовки в акробатическом рок-н-ролле», Фізична культура, спорт та здоров'я, № 5, С. 116 - 120.

5. Сениця А. І., Сениця М. М., Передерій А. В. (2010), Спортивна акробатика: навч. програма для ДЮСШ. Вінниця, C. $50-92$ c.

6. Adashevskiy V. (2013), «Physical Mathematical Modelling of Difficult Elements of Acrobatic Rock-and-Roll, Physical education of students", Vol. 3, pp. 3-10.

7. Anca I. (2016), «Comparative study between athletes in rhythmic gymnastics and dance anatomic and physiologic and development specific force», Physical Education \& Sport Science, Vol. 16, No. 2, pp. 477-783.

8. Blasing B., Calvo-Merino B., Cross E. S., Jola C., Honisch J., Stevens C. J. (2012), «Neurocognitive control in dance perception and performance», Acta Psychologica, Vol. 139 No. 2, pp. 300-308.

9. Hopper C., Fisher B., Munoz K. (2008), Physical activity and nutrition for health, Human Kinetics, Champaign, pp. 258-260.

10. Kim N. (2013), «Reevaluating the Aims of Modern Dance Training in Korea: Toward a Whole Dancer», Journal of Dance Education, Vol. 13 No. 2, pp. 29-32.

11. Kravchuk T. M., Golenkova Yu.V., Sanzharova N. M., Katrechko I. B. (2020), «Influence of means of parterre gymnastics on physical fitness of young athletes in acrobatic rock and roll», Health, sport, rehabilitation, Vol. 6 No. 3, p. 18-25.

Стаття надійшла до редакції: 01.02.2021 р.

Опубліковано: 22.02.2021 p.

Аннотация. Михаил Марченков, Елена Насонкина. Повышение уровня развития силовых способностей спортсменов в возрасте 10-11 лет в акробатическом рок-н-роле. Цель: обосновать эффективность авторской программы развития силовых способностей спортсменов 10-11 лет занимающихся акробатическим рок-н-роллом. Материал и методы: исследование проводилось в период с сентября 2019 по октябрь 2020 году на базе клуба акробатического рок-н-ролла «SUMMIT» г. Харьков. В исследовании приняло участие 20 юных спортсменов в возрасте 10-11 лет( 10 мальчиков и 10 девочек). Все исследуемые спортсмены занимались в группе предварительной базовой подготовки 1-го года обучения. В работе были использованы следующие методы: анализ и обобщение научно-методической литературы; педагогический эксперимент; методы математической статистики. Результаты: учитывая уровень физической подготовленности спортсменов, было разработано тренировочную программу комплексного развития силовых способностей юных спортсменов в возрасте 10-11 лет, которые занимаются акробатическим рок-н-роллом. Программа предусматривала повышение уровня развития силовых способностей мышц: рук, плечевого пояса, шеи, туловища и ног. Внедрение программы подготовки способствовала повышению уровня развития силовых способностей мышц: верхнего плечевого пояса на 17,5\% у юношей и на 22\% у девушек; мышц туловища на 12,6\% у юношей 
и на 10,2\% у девушек; взрывной силы мышц ног на 0,9\% у юношей и на 0,6\% девушек. Выводы: в результате проведенного констатирующего эксперимента с применением специально разработанной тренировочной программы у юношей достоверно повысился уровень развития силовых способностей мышц верхнего плечевого пояса и туловища (р <0,05-0,001). У девушек, в результате внедрения разработанной тренировочной программы, достоверно повысился уровень развития силовых способностей мышц верхнего плечевого пояса $(p<0,05-0,001)$.

Ключевые слова: акробатический рок-н-ролл; силовые способности; тренировочная программа, силовая подготовка; этап предварительной базовой подготовки.

Abstract. Mykhailo Marchenkov, Olena Nasonkina. Increasing the development level of strength abilities of athletes aged 10-11 in acrobatic rock and roll. Purpose: to substantiate the effectiveness of the author's program for the development of strength abilities of athletes aged 10-11 engaged in acrobatic rock and roll. Material and methods: the study was conducted in the period from September 2019 to October 2020 on the base of the acrobatic rock and roll club "SUMMIT" in Kharkiv. The study involved 20 young athletes from 10 to 11 years old ( 10 boys and 10 girls). All studied athletes were engaged in the group of preliminary basic training of the 1 st year of training. The following methods were used in the work: analysis and generalization of scientific and methodological literature; pedagogical experiment; methods of mathematical statistics. Results: considering the level of physical fitness of athletes, a training program was developed for the integrated development of strength abilities of young athletes aged 10-11 years, who are engaged in acrobatic rock and roll. The program provided for an increase in the level of development of the strength abilities of the muscles: arms, shoulder girdle, neck, torso, and legs. The introduction of the training program helped to increase the level of development of muscle strength: the upper shoulder girdle by $17.5 \%$ in boys and $22 \%$ in girls; torso muscles by $12.6 \%$ in boys and $10.2 \%$ in girls; explosive force of leg muscles by $0.9 \%$ in boys and $0.6 \%$ of girls. Conclusions: because of the ascertaining experiment with the use of a specially developed training program in young men there was a significant increase of the development strength abilities level of the muscles of the upper shoulder girdle and torso $(p<0,05-0,001)$. As for girls, because of the implementation of the developed training program, the development strength abilities level of the muscles of the upper shoulder girdle significantly increased $(p<0.05-0.001)$.

Keywords: acrobatic rock and roll; strength abilities; training program, strength training, stage of preliminary basic preparation.

\section{References}

1. Batieieva, N. P. (2012), «Factor structure of the special physical preparedness of athletes highly skilled in acrobatic rock and roll», Slobozhans'kyy naukovo-sportyvnyy visnyk. No 3, pp. 69-74. (in Ukr.).

2. Kaluzhna, O. (2010), «Physical training in the training process of dancers at the stage of preliminary basic training», Teoriya $i$ metodyka fizychnoho vykhovannya i sportu. No 2, pp. 12-16. (in Ukr.).

3. Kyzim, P. N. (2005), «Model Characteristics of Special Physical Fitness of Highly Qualified Athletes in Acrobatic Rock-and-Roll», Slobozans 'kij naukovo-sportivnij visnik, No. 8, pp. 103-105. (in Ukr.).

4. Lutsenko, L.S., Makurin, Yu. K., Mullagildina, A. Ya. (2002), "Means and methods of training at the stage of initial training in acrobatic rock and roll», Fizychna kul'tura, sport ta zdorov’ya, № 5, pp. 116 - 120. (in Russ).

5. Senytsia, A. I., Senytsia M. M., Perederii A. V. (2010), Sportyvna akrobatyka: navch. prohrama dlia DiuSSh, Vinnytsia, pp. 50-92. (in Ukr.).

6. Adashevskiy, V. (2013), «Physical Mathematical Modelling of Difficult Elements of Acrobatic Rock-and-Roll, Physical education of students». Vol. 3, pp. 3-10. (in Eng.).

7. Anca, I. (2016), «Comparative study between athletes in rhythmic gymnastics and dance anatomic and physiologic and development specific force», Physical Education \& Sport Science, Vol. 16, No. 2, pp. 477-783. (in Eng.).

8. Blasing, B., Calvo-Merino, B., Cross, E.S., Jola, C., Honisch, J., Stevens, C.J. (2012), «Neurocognitive control in dance perception and performance», Acta Psychologica. Vol. 139 No. 2, pp. 300-308. (in Eng.).

9. Hopper, C., Fisher, B., Munoz, K. (2008), Physical activity and nutrition for health, Human Kinetics, Champaign, pp. 258-260. (in Eng.).

10. Kim, N. (2013), «Reevaluating the Aims of Modern Dance Training in Korea: Toward a Whole Dancer», Journal of Dance Education. Vol. 13 No. 2, pp. 29-32. (in Eng.).

11. Kravchuk, T. M., Golenkova, Yu.V., Sanzharova, N. M., Katrechko, I. B. (2020), «Influence of means of parterre gymnastics on physical fitness of young athletes in acrobatic rock and roll», Health, sport, rehabilitation. Vol. 6 No. 3, p. 18-25. (in Eng.).

Received: 01.02.2021.

Published: 22.02.2021.

\section{Відомості про авторів / Information about the Authors}

Марченков Михайло Костянтинович: Харківська державна академія фізичної культури: вул. Клочківська, 99. м. Харків, 61058, Україна.

Марченков Михаил Константинович: Харьковская государственная академия физической культуры: ул. Клочковская, 99, г. Харьков, Украина.

Mykhailo Marchenkov: Kharkov State Academy of Physical Culture: Klochkovskaya 99, Kharkov, 61058, Ukraine.

ORCID.ORG/0000-0002-7640-8972

E-mail: marchenkov.mihail68@gmail.com

Насонкіна Олена Юріївна: Харківська державна академія фізичної культури: вул. Клочківська 99, Харків, 61058, Україна. Насонкина Елена Юрьевна: Харьковская государственная академия физической культуры: ул. Клочковская 99, г. Харьков, 61058, Украина.

Olena Nasonkina: Kharkiv State Academy of Physical Culture: Klochkivska str. 99, Kharkiv, 61058, Ukraine.

ORCID.ORG/0000-0002-6127-932X

E-mail: nasonkinaelena@gmail.com 